\title{
RIZATRIPTAN BENZOATE FAST DISSOLVING TABLETS FOR QUICK RELIEVE OF MIGRAINE: DESIGN, DEVELOPMENT AND CHARACTERIZATION
}

BY

Fathy Ibrahim Abd-Allah

FROM

\author{
Department of Pharmaceutics and Industrial Pharmacy, Faculty of Pharmacy, Alazhar \\ University, Cairo, Egypt.
}

\begin{abstract}
Objective: Rizatriptan benzoate $(\mathrm{RB})$ is a new generation anti-migraine drug. After oral administration, the peak plasma concentrations $\left(\mathrm{t}_{\max }\right)$ occur in about 1 to $2.5 \mathrm{hrs}$ depending on the formulation and the bioavailability which is about 40 to $45 \%$. Food may delay the $t_{\max }$ by about 1 hour. The aim of this work was to design and develop fast dissolving tablets of RB to improve the bioavailability and patient compliance applying the Mixture Experimental Design. Methods: Twenty formulations were prepared by direct compression each containing $14.53 \mathrm{mg}$ of RB equivalent to $10 \mathrm{mg}$ Rizatriptan with different proportions of superdisintegrants $\left(X_{1}-X_{3}\right)$ according to the experimental design. The independent factors selected were the percentages of: Croscarmellose sodium $\left(X_{1}\right)$, Explotab $\left(X_{2}\right)$ and Polyplasdone XL $10\left(X_{3}\right)$. The dependent variables investigated were: hardness $\left(Y_{1}\right)$, disintegration time $\left(Y_{2}\right)$ and cumulative $\%$ drug release after 10 minutes $\left(Y_{3}\right)$. The formulations were evaluated for the pre-compression parameters to assess the powder compressibility and flowability (bulk and tapped density, Hausner's ratio, Carr's index and angle of repose) as well as the post-compression parameters (weight variation, friability, hardness, disintegration time, wetting time, water absorption ratio, drug content and in-vitro drug release). The optimized formulation was prepared and evaluated in the same manner. Results: All the evaluated parameters, either for powder blend or for the compressed tablets, were within the acceptable limits. The values of dependent variables ranged between $3.13-3.68 \mathrm{~kg} / \mathrm{cm}^{2} ; 12.23-21.81 \mathrm{sec}$; and $94.44-99.83 \%$ for $Y_{1}, Y_{2}$ and $Y_{3}$ respectively. Polynomial regression equations for the variables $\left(Y_{1}-Y_{3}\right)$ were generated and the quantitative effects of $X_{1}-X_{3}$ at different levels on $Y_{1}-Y_{3}$ could be predicted. Surface response and contour plots were plotted. The optimal ratios of different disintegrants were used to prepare the optimized formulation. The difference between the predicted and the observed data for the optimized formula were minimal. Conclusions: The use of direct compression technique and the mixture experimental design succeeded to produce fast dissolving tablets of RB with optimal hardness, minimal disintegration time and maximal in vitro drug release. The quantitative effects of the selected factors tested on the different variables were explored. Based on the obtained results, fast dissolving tablets of $\mathrm{RB}$ could be a potential dosage form for quick relieve of migraine patients.
\end{abstract}

Key words: Fast Dissolving tablets, Rizatriptan benzoate, Experimental Design 


\section{INTRODUCTION}

The oral cavity is still the attractive site for drug administration because of ease and versatility of use. Fast dissolving tablets, also known as fast melting, fast dispersing, rapid dissolve, rapid melt, and quick disintegrating tablets, disintegrate in the mouth without chewing and there is no need for water to facilitate swallowing (Chopda et. al., 2014).

All fast dissolving tablets approved by FDA are classified as orally disintegrating tablets. Recently, the European Pharmacopeia adopted the term orodispersible tablet for a tablet that disperses or disintegrates in the mouth in less than 3 minutes before swallowing. Such a tablet disintegrates into smaller granules, or melts in the mouth to a gel-like structure and allows easy swallowing by patients (Patidar et. al., 2011).

One of the advantages of orodispersible tablets is to provide quick onset of action within few seconds as the oro-mucosal absorption of drug occurs directly from the site of administration to the systemic circulation avoiding first pass metabolism. Various techniques have been used to formulate fast dissolving tablets. The most common preparation methods are molding, lyophilization, direct compression, cotton-candy, spray drying, and sublimation ((Parakh and Gothoskar, 2003; Evren et al., 2014). Each one of these has advantages and disadvantages.

Direct compression represents one of the techniques that require the incorporation of superdisintegrants into the formulation and the use of highly water soluble excipients to achieve fast tablet disintegration (Indurwade, 2002). This technique does not require the use of water or heat during the formulation procedure and is the ideal method for moisture and heat-labile drugs. It is inexpensive, most convenient and produces tablets of sufficient mechanical integrity without the use of complicated unit operations (Parshu et al., 2012).

Design of Experiments (DOE), also called statistical experimental design, is a wellestablished concept for planning of experiments and generating useful data. An important application of DOE is the preparation and modification of mixtures. It involves the changing in mixture composition and exploring how such changes will affect the properties of the mixture in an attempt to find the formulation (or formulations) that produce the best response (Cornell, 1990, Eriksson et al., 1998; Martinello et al., 2006).

Rizatriptan benzoate $(\mathrm{RB})$ is a potent and selective 5-hydroxytryptamine $1 \mathrm{~B} / 1 \mathrm{D}$ receptor agonist and is considered more effective than the traditional triptans for the treatment of acute migraine attack (Sanders et al., 2006). A $10 \mathrm{mg}$ dose of Rizatriptan is equipotent to a $100 \mathrm{mg}$ of sumatriptan, the traditional antimigraine drug (Martindale, 2002). RB has poor bioavailability (40 to $45 \%$ ) may be because of liver metabolism and incomplete drug absorption and its $t_{\max }$ is 1 to $2.5 \mathrm{hrs}$ depending on the formulation. On oral administration of intact tablet, it was found that food may delay the $t_{\max }$ by about $1 \mathrm{hr}$. As migraine sufferers have markedly reduced functional ability, they would be benefited from quick treatment that helps them to resume their functional activities as quickly as possible.

The objectives of this study were to design and develop fast dissolving tablets of RB in order to solve the problem of difficulty in swallowing leading to better patient compliance, improve onset of action to enhance both the safety and efficacy of drug molecules. DOE was applied to study the effects of superdisintegrant concentrations on the hardness, disintegration time and dissolution time. DOE was also to generate the optimized formulation which was prepared and characterized in the same manner. 


\section{MATERIAL AND METHODS Materials}

RB was obtained from Zhejiang Supor Pharmaceuticals Co. Ltd. (Shaoxing, China); Croscarmellose sodium (Ac-Di-Sol, "modified cellulose gum NF", was obtained from FMC Corporation (Philadelphia, PA, USA); Explotab (Sodium Starch Glycolate), Emcocel ${ }^{\circledR} 90 \mathrm{M}$ (Microcrystalline Cellulose) and Pruv ${ }^{\circledR}$ (Sodium Stearyl Fumarate) were obtained from JRS Pharma (GMBH \& Co. KG, Rosenberg, Germany); Crospovidone NF (Polyplasdone XL10) from ISP Technologies, (Ashland, KY, USA); Pearlitol ${ }^{\circledR}$ 200SD-Mannitol was obtained from Roquette Freres, (France); Aerosil 200 was obtained from Cabot Corporation, (Boston, MA, USA); Aspartame was obtained from Nutrasweet LTD. All other materials were of analytical grades and were used without further purification.

\section{Methods}

\section{Experimental Design}

A mixture experimental design of the Extreme vertices model was employed to statistically optimize the combination of superdisintegrants for development of $\mathrm{RB}$ fast dissolving tablets with optimal hardness, minimal disintegration time and maximal in vitro drug release. Generation and evaluation of the DOE was performed with Statgraphics ${ }^{\circledR}$ Centurion XV Software Version 15.2.05 (StatPoint Technologies, Inc., Warrenton, VA, USA). The selected superdisintegrants: Croscarmellose sodium $\left(X_{1}\right)$, Explotab $\left(X_{2}\right)$, and Polyplasdone XL $10\left(X_{3}\right)$ were used in different proportions for construction of 20 formulae in randomized runs by the mixture design. The dependent variables investigated were the hardness $\left(Y_{1}\right)$, in vitro disintegration time $\left(Y_{2}\right)$ and the cumulative \% release of RB from fast dissolving tablets after 10 min $\left(Y_{3}\right)$. Table 1 summarizes the independent factors and intervals selected to perform the mixture design.

Table 1: Factors and intervals selected to perform the mixture of superdisintegrants

\begin{tabular}{|l|l|l|}
\hline \multirow{2}{*}{ Independent Factors } & Level \\
\cline { 2 - 3 } & Low & High \\
\hline Croscarmellose sodium $\left(X_{1}\right)$ & 0.0 & 0.6 \\
\hline Explotab $\left(X_{2}\right)$ & 0.0 & 0.7 \\
\hline Polyplasdon XL 10 $\left(X_{3}\right)$ & 0.0 & 0.5 \\
\hline
\end{tabular}

\section{Formulation of RB fast dissolving tablets}

$\mathrm{RB}$ fast dissolving tablets were prepared by Direct Compression Technique. All the ingredients RB, Croscarmellose sodium, Explotab, Polyplasdon XL 10, Pearlitol, Emcocel and Aspartame were sifted through \# 40 mesh and weighed, placed in bin blender and mixed for 15 minutes at $14 \mathrm{rpm}$ followed by lubrication with sodium stearyl fumarate (which was previously sifted through \# 60 meshes) for $5 \mathrm{~min}$ at $14 \mathrm{rpm}$ (Hindustan et al., 2010). The lubricated blends ready for compression were compressed into tablets using flat face $8 \mathrm{~mm}$ size punch to get tablet of $100 \mathrm{mg}$ using single punch Erweka Tablet compression machine (XL8D-type). The composition of batches as per the mixture design was shown in Table 2. 
Table 2: Composition of RB fast dissolving tablets according to the mixture design:

\begin{tabular}{|c|c|c|c|c|c|c|c|c|c|}
\hline $\begin{array}{c}\text { Run } \\
\text { code }\end{array}$ & $\mathbf{R B}$ & $\boldsymbol{X}_{\mathbf{1}}$ & $\boldsymbol{X}_{\mathbf{2}}$ & $\boldsymbol{X}_{\mathbf{3}}$ & Emcocel & Pearlitol® & Aspartame & $\begin{array}{c}\text { Aerosil } \\
\text { 200 }\end{array}$ & $\begin{array}{c}\text { Pruv® } \\
\text { JRS }\end{array}$ \\
\hline F1 & 14.53 & 3 & 2 & 0 & 30 & 44.47 & 5 & 0.5 & 0.5 \\
\hline F2 & 14.53 & 3 & 0 & 2 & 30 & 44.47 & 5 & 0.5 & 0.5 \\
\hline F3 & 14.53 & 1.5 & 3.5 & 0 & 30 & 44.47 & 5 & 0.5 & 0.5 \\
\hline F4 & 14.53 & 0 & 3.5 & 1.5 & 30 & 44.47 & 5 & 0.5 & 0.5 \\
\hline F5 & 14.53 & 2.5 & 0 & 2.5 & 30 & 44.47 & 5 & 0.5 & 0.5 \\
\hline F6 & 14.53 & 0 & 2.5 & 2.5 & 30 & 44.47 & 5 & 0.5 & 0.5 \\
\hline F7 & 14.53 & 2.34 & 1.96 & 0.7 & 30 & 44.47 & 5 & 0.5 & 0.5 \\
\hline F8 & 14.53 & 2.34 & 0.96 & 1.7 & 30 & 44.47 & 5 & 0.5 & 0.5 \\
\hline F9 & 14.53 & 1.59 & 2.71 & 0.7 & 30 & 44.47 & 5 & 0.5 & 0.5 \\
\hline F10 & 14.53 & 0.84 & 2.71 & 1.45 & 30 & 44.47 & 5 & 0.5 & 0.5 \\
\hline F11 & 14.53 & 2.09 & 0.96 & 1.95 & 30 & 44.47 & 5 & 0.5 & 0.5 \\
\hline F12 & 14.53 & 0.84 & 2.21 & 1.95 & 30 & 44.47 & 5 & 0.5 & 0.5 \\
\hline F13 & 14.53 & 3 & 1 & 1 & 30 & 44.47 & 5 & 0.5 & 0.5 \\
\hline F14 & 14.53 & 2.25 & 2.75 & 0 & 30 & 44.47 & 5 & 0.5 & 0.5 \\
\hline F15 & 14.53 & 2.75 & 0 & 2.25 & 30 & 44.47 & 5 & 0.5 & 0.5 \\
\hline F16 & 14.53 & 0.75 & 3.5 & 0.75 & 30 & 44.47 & 5 & 0.5 & 0.5 \\
\hline F17 & 14.53 & 0 & 3 & 2 & 30 & 44.47 & 5 & 0.5 & 0.5 \\
\hline F18 & 14.53 & 1.25 & 1.25 & 2.5 & 30 & 44.47 & 5 & 0.5 & 0.5 \\
\hline F19 & 14.53 & 1.67 & 1.92 & 1.41 & 30 & 44.47 & 5 & 0.5 & 0.5 \\
\hline F20 & 14.53 & 3 & 2 & 0 & 30 & 44.47 & 5 & 0.5 & 0.5 \\
\hline
\end{tabular}

\section{Pre-compression evaluation of the powder blend:}

The blend of each formula was evaluated by mass-volume relationship (for bulk and tapped density, Hausner's ratio, and Carr's index) and flow properties (angle of repose) to evaluate the compressibility and flow properties (Kumara et al., 2012).

\section{Post compression evaluation of the tablets}

\section{Weight variation test}

The weight variation test was carried out in order to ensure uniformity in the weight of tablets in a batch. The total weight of 20 tablets randomly selected from whole batch was determined and the average was calculated. The individual weights of the tablets were also determined accurately and the weight variation was calculated (Nyol et al., 2013).

\section{Friability test}

The friability was measured in an Erweka Friabilator, type PTF1 (Pharmatest, Hainburg, Germany). In each run 20 tablets were carefully dedusted, weighed and rotated in the tester 100 times at $25 \mathrm{rpm}$ then the tablets were dedusted and weighed again. Percentage friability was calculated from the loss in weight as given in the following equation.

Friability \% (\% loss in weight $)=[(\mathrm{W} 1-\mathrm{W} 2) / \mathrm{W} 1] \times 100$

Where W1 and W2 were tablet weights before and after test, respectively (Battu et al., 2007). 


\section{Hardness test}

Tablet crushing strength or hardness (i.e. the force required to break a tablet in a diametric compression) was measured using $4 \mathrm{M}$ tablet hardness tester (Schleuniger, Switzerland) (Battu et al., 2007).

\section{In vitro disintegration time}

In-vitro Disintegration time was measured by dropping a tablet in a beaker containing 5 $\mathrm{ml}$ of $\mathrm{pH} 6.8$ Phosphate buffer at $37 \pm 0.5^{\circ}$ and the time required for complete dispersion was determined. Three tablets from each formulation were randomly selected and in-vitro disintegration times were determined (Mohire et al., 2009).

\section{Wetting time and water absorption ratio}

The wetting time of the tablet was measured by placing a tablet on a piece of tissue paper folded twice in a small Petri dish (Internal diameter $=6.5 \mathrm{~cm}$ ) containing ten millimeters of water. Eosin, a water soluble dye, was added to the petri dish. A tablet was carefully placed on the surface of the tissue paper. The time required for water to reach upper surface of the tablet was noted as a wetting time. Water absorption ratio $(\mathrm{R})$ was then determined according to the following equation.

$\mathrm{R}=[(\mathrm{Wa}-\mathrm{Wb}) / \mathrm{Wb}] \times 100 \mathrm{Where} \mathrm{Wb}$ and $\mathrm{Wa}$ were tablet weights before and after water absorption, respectively (Battu et al., 2007; Mukeshi et al., 2009).

\section{Drug content uniformity}

The assay of tablets was performed by HPLC using Agilent 1200 Series, Agilent Technologies (Deutschland GmbH, Waldbronn, Germany), and SUPLECO Analytical-C18 column $(250 \times 4.6 \mathrm{id} \mathrm{mm}, 5 \mu \mathrm{m})$. The mobile phase used was triethylamin:acetonitrile $(90: 10)$ (Que et al., 2006). The flow rate was set as $1.8 \mathrm{ml} / \mathrm{min}$ with a column temperature of $25^{\circ}$. The injected volume was $20 \mu \mathrm{l}$ and an UV detector was used (226 nm).

For content uniformity test, ten tablets of each batch were weighed and powdered. Aliquot of this powder containing $\mathrm{RB}$ equivalent to $10 \mathrm{mg}$ of Rizatriptan was accurately weighed, suspended in approximately $50 \mathrm{ml}$ of $0.1 \mathrm{~N} \mathrm{HCl}$ and shaken for $15 \mathrm{~min}$. Final volume was adjusted to $100 \mathrm{ml}$ with $0.1 \mathrm{~N} \mathrm{HCl}$ and filtered (Whatmann No.1 filter paper). From this 10 $\mathrm{ml}$ was diluted to $100 \mathrm{ml}$. The final volume was made by taking $2 \mathrm{ml}$ of above solution and diluted to $10 \mathrm{ml}$ with $0.1 \mathrm{~N} \mathrm{HCl}$. Absorbance of this solution was recorded against a reagent blank and the mean percent drug content was calculated as an average of three determinations (Keny et al., 2010).

\section{In vitro release studies}

In vitro dissolution of $\mathrm{RB}$ fast dissolving tablets was studied in USP dissolution test apparatus type II employing a paddle stirrer at $50 \mathrm{rpm}$ using $900 \mathrm{ml}$ of water at $37 \pm 0.5^{\circ}$ as dissolution medium (Que et al., 2006). One tablet was used in each test. Aliquots of dissolution medium $(5 \mathrm{ml})$ were withdrawn at specific intervals of time $(2 \mathrm{~min})$ filtered through (Whatmann No.1 filter paper) and analyzed for drug content by measuring the absorbance at $280 \mathrm{~nm}$ using UV/Vis spectrophotometer against a reagent blank (water). The volume withdrawn at each time interval was replaced with fresh quantity of dissolution medium. Cumulative percent drug released was calculated and plotted against time (Keny et al., 2010). 


\section{RESULTS AND DISCUSSION \\ Evaluation of powder blends}

The flow properties of powder blends of the formulations were evaluated and illustrated in Table 3. Bulk density of various formulations was found to be in the range of $0.487-0.514$ $\mathrm{g} / \mathrm{cm}^{3}$ and the tapped density ranged from 0.571 to $0.601 \mathrm{~g} / \mathrm{cm}^{3}$. From the observed data, the powder blends of all the formulations had Hausner ratio and Carr's index values ranging from 1.14 to 1.21 and 12.80 to $17.73 \%$, respectively. The angle of repose ranged from 20.11 to $27.49^{\circ}$. The results provide strong evidence that these blends had excellent flow properties and could be used for tablet manufacture by direct compression. In general, powders with angles of repose greater than $60^{\circ}$ would have unsatisfactory flow properties, while powders with minimum angle of repose up to $25^{\circ}$ would have excellent flowability (Carr, 1965).

Table 3: Evaluation of powder blend of drug and excipients

\begin{tabular}{|c|c|c|c|c|c|}
\hline $\begin{array}{l}\text { Run } \\
\text { Code }\end{array}$ & $\begin{array}{l}\text { Bulk density } \\
\qquad\left(\mathrm{g} / \mathrm{cm}^{3}\right)\end{array}$ & $\begin{array}{l}\text { Tapped } \\
\text { density } \\
\left(\mathrm{g} / \mathrm{cm}^{3}\right)\end{array}$ & $\begin{array}{l}\text { Hausner } \\
\text { ratio }\end{array}$ & $\begin{array}{c}\text { Carr's } \\
\text { index } \\
(\%)\end{array}$ & $\begin{array}{c}\text { Angle of repose } \\
\left(\left(^{\circ}\right)\right.\end{array}$ \\
\hline F1 & $0.514 \pm 0.007$ & $0.593 \pm 0.005$ & 1.15 & 13.32 & $22.13 \pm 0.143$ \\
\hline $\mathrm{F} 2$ & $0.501 \pm 0.006$ & $0.588 \pm 0.009$ & 1.17 & 14.79 & $23.84 \pm 0.125$ \\
\hline F3 & $0.494 \pm 0.009$ & $0.571 \pm 0.005$ & 1.15 & 13.45 & $26.15 \pm 0.119$ \\
\hline $\mathrm{F} 4$ & $0.502 \pm 0.005$ & $0.583 \pm 0.006$ & 1.16 & 13.89 & $20.93 \pm 0.257$ \\
\hline F5 & $0.495 \pm 0.007$ & $0.574 \pm 0.007$ & 1.15 & 13.76 & $26.49 \pm 0.243$ \\
\hline F6 & $0.504 \pm 0.006$ & $0.578 \pm 0.008$ & 1.14 & 12.80 & $20.11 \pm 0.132$ \\
\hline F7 & $0.491 \pm 0.008$ & $0.584 \pm 0.004$ & 1.18 & 15.92 & $26.89 \pm 0.174$ \\
\hline F8 & $0.497 \pm .005$ & $0.582 \pm 0.004$ & 1.17 & 14.60 & $21.46 \pm 0.221$ \\
\hline F9 & $0.499 \pm .004$ & $0.589 \pm 0.007$ & 1.18 & 15.28 & $24.70 \pm 0.413$ \\
\hline F10 & $0.487 \pm 0.005$ & $0.583 \pm 0.003$ & 1.19 & 16.46 & $24.26 \pm 0.227$ \\
\hline F11 & $0.494 \pm 0.005$ & $0.587 \pm 0.006$ & 1.18 & 15.84 & $27.49 \pm 0.322$ \\
\hline F12 & $0.487 \pm 0.004$ & $0.592 \pm 0.003$ & 1.21 & 17.73 & $22.23 \pm 0.040$ \\
\hline F13 & $0.503 \pm 0.009$ & $0.596 \pm 0.006$ & 1.18 & 15.60 & $20.12 \pm 0.082$ \\
\hline F14 & $0.499 \pm 0.007$ & $0.598 \pm 0.006$ & 1.19 & 16.55 & $26.55 \pm 0.262$ \\
\hline F15 & $0.502 \pm 0.007$ & $0.587 \pm 0.008$ & 1.16 & 14.48 & $21.27 \pm 0.092$ \\
\hline F16 & $0.506 \pm 0.009$ & $0.596 \pm 0.005$ & 1.17 & 15.10 & $23.90 \pm 0.143$ \\
\hline F17 & $0.504 \pm 0.005$ & $0.597 \pm 0.007$ & 1.18 & 15.57 & $24.54 \pm 0.234$ \\
\hline F18 & $0.503 \pm 0.004$ & $0.601 \pm 0.006$ & 1.19 & 16.30 & $22.20 \pm 0.093$ \\
\hline F19 & $0.502 \pm 0.005$ & $0.592 \pm 0.006$ & 1.17 & 15.20 & $22.98 \pm 0.212$ \\
\hline $\mathrm{F} 20$ & $0.506 \pm 0.007$ & $0.594 \pm 0.005$ & 1.17 & 14.8 & $22.13 \pm 0.142$ \\
\hline
\end{tabular}

\section{Evaluation of tablets}

The results of the evaluation parameters for the developed tablets were shown in Table 4. Weight variation was found within the specification of the USP limits. The average weight of 20 tablets of all formulations was found to be in the range of 98.85 to $101.5 \mathrm{mg}$. The ranges of friability and hardness were 0.25 to $0.46 \%$, and 3.13 to $3.68 \mathrm{~kg} / \mathrm{cm}^{2}$, respectively. The lower friability results $(<1.0 \%)$ indicate that the tablets may not break during handling on machines 
and/or shipping. Wetting time and water absorption ratio ranged from 11.30 to $18.57 \mathrm{~s}$ and 66.74 to $77.30 \%$, respectively. Drug content of all the formulations was in the range of 97.78 to $100.35 \%$.

All formulations showed in vitro disintegration time less than 22 seconds. The in vitro disintegration time was rapid with Polyplasdone XL10 containing formulae (12.23, 13.30 and13.82 sec for F5, F6 and F18, respectively) and delayed with Explotab containing formulae (20.53, 20.73, 20.84 and $21.81 \mathrm{sec}$ for F17, F4, F14 and F3, respectively), while Croscarmellose sodium containing formulae were midway between both groups. The rapid disintegration obtained with Polyplasdone XL 10 might be explained by the fast uptake of water from the medium, followed by swelling and bursting. In contrast, croscarmellose sodium and Explotab are characterized by high gelling tendency which causes swelling of tablet mass with subsequent retardation of disintegration.

Wetting is related to the inner structure of the tablets and hydrophobicity of the components. This may be due to the fact that Explotab is disintegrated by swelling mechanism leading to longer wetting time. Polyplasdone XL 10 and croscarmellose sodium perform their disintegrating action by wicking through capillary action and fibrous structure, respectively with minimum gelling (Yutaka et al., 2002). After contact with water, the tablets containing Explotab swelled, the outer edge appeared gel-like. Tablets containing Polyplasdone XL 10 quickly wicked water and were hydrated, but were soft as compared with tablets prepared with croscarmellose sodium and Explotab. The centers of the tablets with Explotab and croscarmellose sodium remained dry and hard (Kakade et al., 2010).

In vitro dissolution studies of the prepared tablets were performed in water using USP dissolution apparatus type II at different time intervals as presented in (Figures 1-4). All formulations showed maximum dissolution rate of more than $94.44 \%$ within 10 minutes. The rapid dissolving concept in case of RB could particularly be of a great importance in relieving migraine attacks. Formulations F18, F11, and F13 which contained combinations of the three superdisintegrants with different proportions showed drug release of 99.83, 99.69, and 98.49\% respectively (Figures 3 and 4), at the end of 10 minutes with the order of relative efficiency as Polyplasdone XL $10>$ Croscarmellose sodium >Explotab. Formulations F5, F15, and F2 which contained high concentrations of superdisintegrants, Polyplasdone XL 10, and croscarmellose sodium have recorded drug release of $98.15,97.87$, and $97.45 \%$ respectively, at the end of 10 minutes (Figures 1 and 3). Whereas, the remainder of the formulations which contained two different superdisintegrants in alternative concentration in absence of the third one, and formulations which contained high amount of Explotab had the lowest \% of drug release (96.28, 95.87, and 95.62\% in F4, F9, and F14) at the end of 10 minutes (Figures1-3). This was probably due to formation of viscous plugs by Explotab particles. 
Table 4: Evaluation data of the prepared RB fast dissolving tablets

\begin{tabular}{|c|c|c|c|c|c|c|c|c|}
\hline $\begin{array}{c}\text { Ru } \\
\mathbf{n} \\
\text { cod } \\
\mathbf{e}\end{array}$ & $\begin{array}{c}\text { Weight } \\
\text { (mg) }\end{array}$ & $\begin{array}{c}\text { Friabilit } \\
\text { y }(\%)\end{array}$ & $\begin{array}{c}\text { Hardne } \\
\text { SS } \\
\left(\mathrm{kg} / \mathrm{cm}^{2}\right. \\
)\end{array}$ & $\begin{array}{c}\text { Disintegrati } \\
\text { on time } \\
\text { (sec.) }\end{array}$ & $\begin{array}{l}\text { Wetting } \\
\text { time } \\
\text { (sec.) }\end{array}$ & $\begin{array}{c}\text { Water } \\
\text { absorpti } \\
\text { on ratio }\end{array}$ & $\begin{array}{c}\text { Drug } \\
\text { content } \\
(\%)\end{array}$ & $\begin{array}{c}\text { Drug } \\
\text { release } \\
(\%)\end{array}$ \\
\hline $\mathrm{F} 1$ & $\begin{array}{c}99.87 \pm 0 \\
45\end{array}$ & $\begin{array}{c}0.27 \pm 0.0 \\
1\end{array}$ & $\begin{array}{c}3.65 \pm 0.0 \\
6\end{array}$ & $17.84 \pm 0.17$ & $\begin{array}{c}18.57 \pm 0 . \\
33\end{array}$ & $\begin{array}{c}70.37 \pm 0 \\
50\end{array}$ & $\begin{array}{c}98.34 \pm 0.1 \\
5 \\
\end{array}$ & $\begin{array}{c}94.44 \pm 0 . \\
22\end{array}$ \\
\hline $\mathrm{F} 2$ & $\begin{array}{c}98.85 \pm 0 \\
45\end{array}$ & $\begin{array}{c}0.31 \pm 0.0 \\
1\end{array}$ & $\begin{array}{c}3.44 \pm 0.0 \\
6\end{array}$ & $16.74 \pm 0.13$ & $\begin{array}{c}14.53 \pm 0 . \\
33\end{array}$ & $\begin{array}{c}68.77 \pm 0 \\
50\end{array}$ & $\begin{array}{c}99.47 \pm 0.1 \\
5\end{array}$ & $\begin{array}{c}97.45 \pm 0 . \\
15\end{array}$ \\
\hline $\mathrm{F} 3$ & $\begin{array}{c}101.3 \pm 0 \\
20\end{array}$ & $\begin{array}{c}0.46 \pm 0.0 \\
1\end{array}$ & $\begin{array}{c}3.63 \pm 0.0 \\
2\end{array}$ & $21.81 \pm 0.36$ & $\begin{array}{c}15.34 \pm 0 . \\
28\end{array}$ & $\begin{array}{c}70.27 \pm 0 \\
57\end{array}$ & $\begin{array}{c}99.75 \pm 0.2 \\
7\end{array}$ & $\begin{array}{c}94.49 \pm 0 . \\
26\end{array}$ \\
\hline $\mathrm{F} 4$ & $\begin{array}{c}99.82 \pm 0 \\
10\end{array}$ & $\begin{array}{c}0.39 \pm 0.0 \\
3\end{array}$ & $\begin{array}{c}3.61 \pm 0.0 \\
4\end{array}$ & $20.73 \pm 0.11$ & $\begin{array}{c}14.46 \pm 0 . \\
48\end{array}$ & $\begin{array}{c}68.91 \pm 0 \\
44\end{array}$ & $\begin{array}{c}99.46 \pm 0.3 \\
2\end{array}$ & $\begin{array}{c}96.28 \pm 0 . \\
46\end{array}$ \\
\hline F5 & $\begin{array}{c}99.47 \pm 0 \\
15\end{array}$ & $\begin{array}{c}0.26 \pm 0.0 \\
2\end{array}$ & $\begin{array}{c}3.27 \pm 0.0 \\
5\end{array}$ & $12.23 \pm 0.18$ & $\begin{array}{c}15.52 \pm 0 \\
12\end{array}$ & $\begin{array}{c}67.54 \pm 0 \\
37\end{array}$ & $\begin{array}{c}100.23 \pm 0 \\
38\end{array}$ & $\begin{array}{c}98.15 \pm 0 . \\
68\end{array}$ \\
\hline F6 & $\begin{array}{c}100.3 \pm 0 \\
40\end{array}$ & $\begin{array}{c}0.39 \pm 0.0 \\
2\end{array}$ & $\begin{array}{c}3.51 \pm 0.0 \\
4\end{array}$ & $13.30 \pm 0.25$ & $\begin{array}{c}16.13 \pm 0 . \\
23\end{array}$ & $\begin{array}{c}66.74 \pm 0 . \\
39\end{array}$ & $\begin{array}{c}98.51 \pm 0.2 \\
0\end{array}$ & $\begin{array}{c}96.77 \pm 0 . \\
29\end{array}$ \\
\hline F7 & $\begin{array}{c}99.23 \pm 1 \\
14\end{array}$ & $\begin{array}{c}0.46 \pm 0.0 \\
2\end{array}$ & $\begin{array}{c}3.43 \pm 0.0 \\
3\end{array}$ & $16.27 \pm 1.09$ & $\begin{array}{c}15.25 \pm 0 \\
22\end{array}$ & $\begin{array}{c}70.12 \pm 0 . \\
21\end{array}$ & $\begin{array}{c}99.62 \pm 0.4 \\
7\end{array}$ & $\begin{array}{c}97.14 \pm 0 . \\
41\end{array}$ \\
\hline F8 & $\begin{array}{c}99.27 \pm 0 \\
95\end{array}$ & $\begin{array}{c}0.28 \pm 0.0 \\
3\end{array}$ & $\begin{array}{c}3.36 \pm 0.0 \\
8\end{array}$ & $15.64 \pm 0.46$ & $\begin{array}{c}13.79 \pm 0 . \\
21\end{array}$ & $\begin{array}{c}73.41 \pm 0 \\
36\end{array}$ & $\begin{array}{c}99.70 \pm 0.2 \\
1\end{array}$ & $\begin{array}{c}98.35 \pm 0 . \\
48\end{array}$ \\
\hline F9 & $\begin{array}{c}100.4 \pm 0 \\
12\end{array}$ & $\begin{array}{c}0.33 \pm 0.0 \\
2\end{array}$ & $\begin{array}{c}3.59 \pm 0.0 \\
8\end{array}$ & $19.87 \pm 0.44$ & $\begin{array}{c}12.79 \pm 0 \\
83\end{array}$ & $\begin{array}{c}75.15 \pm 1 \\
20\end{array}$ & $\begin{array}{c}97.78 \pm 0.2 \\
5\end{array}$ & $\begin{array}{c}95.87 \pm 0 \\
56\end{array}$ \\
\hline F10 & $\begin{array}{c}99.87 \pm 0 \\
45\end{array}$ & $\begin{array}{c}0.44 \pm 0.0 \\
1\end{array}$ & $\begin{array}{c}3.39 \pm 0.0 \\
6\end{array}$ & $19.84 \pm 0.09$ & $\begin{array}{c}13.53 \pm 0 \\
33\end{array}$ & $\begin{array}{c}71.97 \pm 0 \\
50\end{array}$ & $\begin{array}{c}98.76 \pm 0.1 \\
5\end{array}$ & $\begin{array}{c}96.32 \pm 0 . \\
24\end{array}$ \\
\hline F11 & $\begin{array}{c}100.3 \pm 0 \\
60\end{array}$ & $\begin{array}{c}0.42 \pm 0.0 \\
3\end{array}$ & $\begin{array}{c}3.37 \pm 0.0 \\
5\end{array}$ & $16.72 \pm 0.11$ & $\begin{array}{c}14.84 \pm 0 . \\
26\end{array}$ & $\begin{array}{c}69.87 \pm 0 \\
26\end{array}$ & $\begin{array}{c}100.35 \pm 0 \\
25\end{array}$ & $\begin{array}{c}99.69 \pm 0 . \\
26\end{array}$ \\
\hline F12 & $\begin{array}{c}99.27 \pm 0 \\
95\end{array}$ & $\begin{array}{c}0.45 \pm 0.0 \\
3\end{array}$ & $\begin{array}{c}3.16 \pm 0.0 \\
8\end{array}$ & $14.64 \pm 0.46$ & $\begin{array}{c}13.57 \pm 0 \\
21\end{array}$ & $\begin{array}{c}74.41 \pm 0 \\
36\end{array}$ & $\begin{array}{c}99.81 \pm 0.2 \\
1\end{array}$ & $\begin{array}{c}98.92 \pm 0 . \\
48\end{array}$ \\
\hline F13 & $\begin{array}{c}100.1 \pm 0 \\
55\end{array}$ & $\begin{array}{c}0.37 \pm 0.0 \\
3\end{array}$ & $\begin{array}{c}3.17 \pm 0.0 \\
5\end{array}$ & $15.07 \pm 0.14$ & $\begin{array}{c}12.56 \pm 0 \\
17\end{array}$ & $\begin{array}{c}77.30 \pm 0 \\
37\end{array}$ & $\begin{array}{c}99.98 \pm 0.3 \\
1\end{array}$ & $\begin{array}{c}98.49 \pm 0 \\
29\end{array}$ \\
\hline F14 & $\begin{array}{c}99.89 \pm 0 \\
45\end{array}$ & $\begin{array}{c}0.28 \pm 0.0 \\
1\end{array}$ & $\begin{array}{c}3.67 \pm 0.0 \\
6\end{array}$ & $20.84 \pm 0.15$ & $\begin{array}{c}11.30 \pm 0 \\
33\end{array}$ & $\begin{array}{c}75.97 \pm 0 \\
50\end{array}$ & $\begin{array}{c}98.39 \pm 0.1 \\
5\end{array}$ & $\begin{array}{c}95.62 \pm 0 . \\
37\end{array}$ \\
\hline F15 & $\begin{array}{c}99.77 \pm 0 . \\
15\end{array}$ & $\begin{array}{c}0.34 \pm 0.0 \\
1\end{array}$ & $\begin{array}{c}3.13 \pm 0.0 \\
5\end{array}$ & $16.56 \pm 0.19$ & $\begin{array}{c}13.69 \pm 0 . \\
28\end{array}$ & $\begin{array}{c}72.06 \pm 0 \\
92\end{array}$ & $\begin{array}{c}99.73 \pm 0.4 \\
7\end{array}$ & $\begin{array}{c}97.87 \pm 0 . \\
29\end{array}$ \\
\hline F16 & $\begin{array}{c}100.0 \pm 0 \\
21\end{array}$ & $\begin{array}{c}0.25 \pm 0.0 \\
2\end{array}$ & $\begin{array}{c}3.55 \pm 0.0 \\
8\end{array}$ & $19.63 \pm 0.13$ & $\begin{array}{c}12.13 \pm 0 . \\
32\end{array}$ & $\begin{array}{c}76.85 \pm 0 \\
25\end{array}$ & $\begin{array}{c}99.20 \pm 0.4 \\
6\end{array}$ & $\begin{array}{c}96.64 \pm 0 . \\
27\end{array}$ \\
\hline F17 & $\begin{array}{c}99.97 \pm 0 . \\
76\end{array}$ & $\begin{array}{c}0.34 \pm 0.0 \\
2\end{array}$ & $\begin{array}{c}3.48 \pm 0.0 \\
5\end{array}$ & $20.53 \pm 0.16$ & $\begin{array}{c}13.26 \pm 0 \\
27\end{array}$ & $\begin{array}{c}75.69 \pm 0 . \\
81\end{array}$ & $\begin{array}{c}99.75 \pm 0.3 \\
0\end{array}$ & $\begin{array}{c}96.46 \pm 0 . \\
38\end{array}$ \\
\hline F18 & $\begin{array}{c}101.5 \pm 0 \\
12\end{array}$ & $\begin{array}{c}0.34 \pm 0.0 \\
2\end{array}$ & $\begin{array}{c}3.32 \pm 0.0 \\
8\end{array}$ & $13.82 \pm 0.44$ & $\begin{array}{c}13.19 \pm 0 . \\
83\end{array}$ & $\begin{array}{c}69.15 \pm 1 . \\
20\end{array}$ & $\begin{array}{c}100.07 \pm 0 \\
25\end{array}$ & $\begin{array}{c}99.83 \pm 0 \\
56\end{array}$ \\
\hline F19 & $\begin{array}{c}100.2 \pm 0 \\
66\end{array}$ & $\begin{array}{c}0.29 \pm 0.0 \\
2\end{array}$ & $\begin{array}{c}3.25 \pm 0.0 \\
7\end{array}$ & $14.31 \pm 0.27$ & $\begin{array}{c}15.82 \pm 0 \\
08\end{array}$ & $\begin{array}{c}75.92 \pm 0 \\
18\end{array}$ & $\begin{array}{c}99.17 \pm 0.2 \\
0\end{array}$ & $\begin{array}{c}97.31 \pm 0 . \\
21\end{array}$ \\
\hline F20 & $\begin{array}{c}100.3 \pm 0 \\
60\end{array}$ & $\begin{array}{c}0.28 \pm 0.0 \\
3\end{array}$ & $\begin{array}{c}3.68 \pm 0.0 \\
5\end{array}$ & $17.79 \pm 0.11$ & $\begin{array}{c}17.49 \pm 0 . \\
26\end{array}$ & $\begin{array}{c}70.87 \pm 0 \\
26\end{array}$ & $\begin{array}{c}98.31 \pm 0.2 \\
5\end{array}$ & $\begin{array}{c}94.58 \pm 0 . \\
26\end{array}$ \\
\hline
\end{tabular}




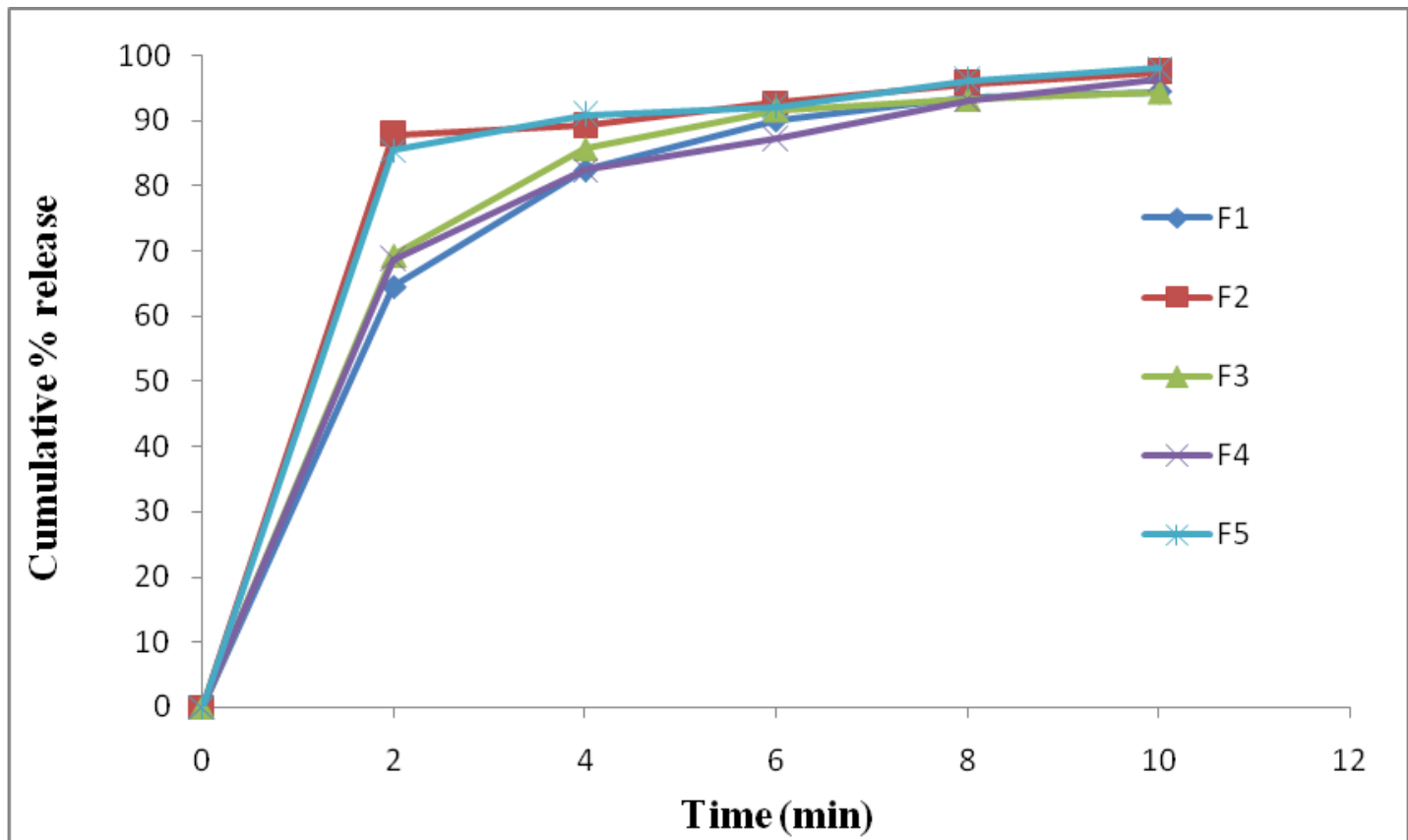

Figure 1: In-Vitro release Profile of formulation F1, F2, F3, F4 and F5

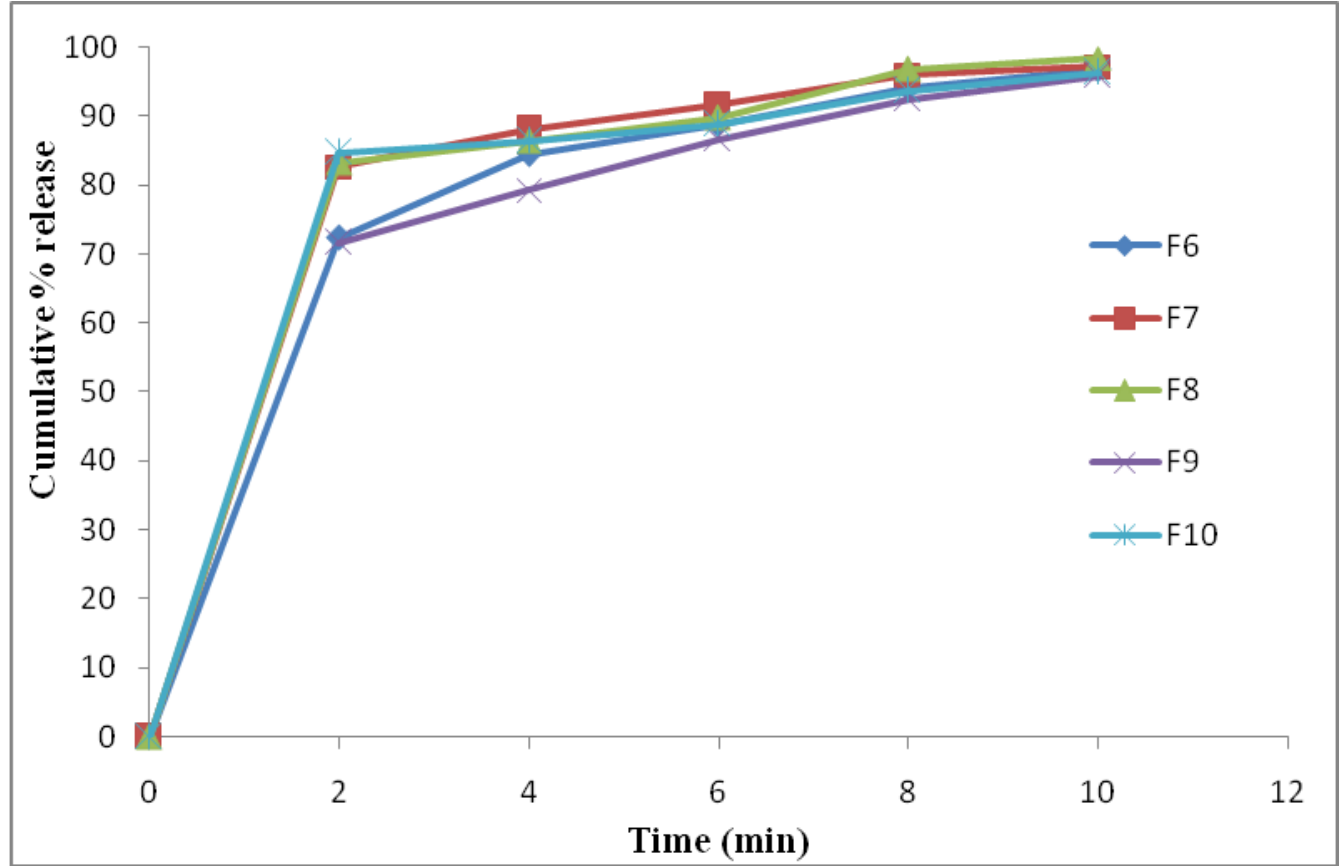

Figure 2: In-Vitro release Profile of formulation F6, F7, F8, F9 and F10 


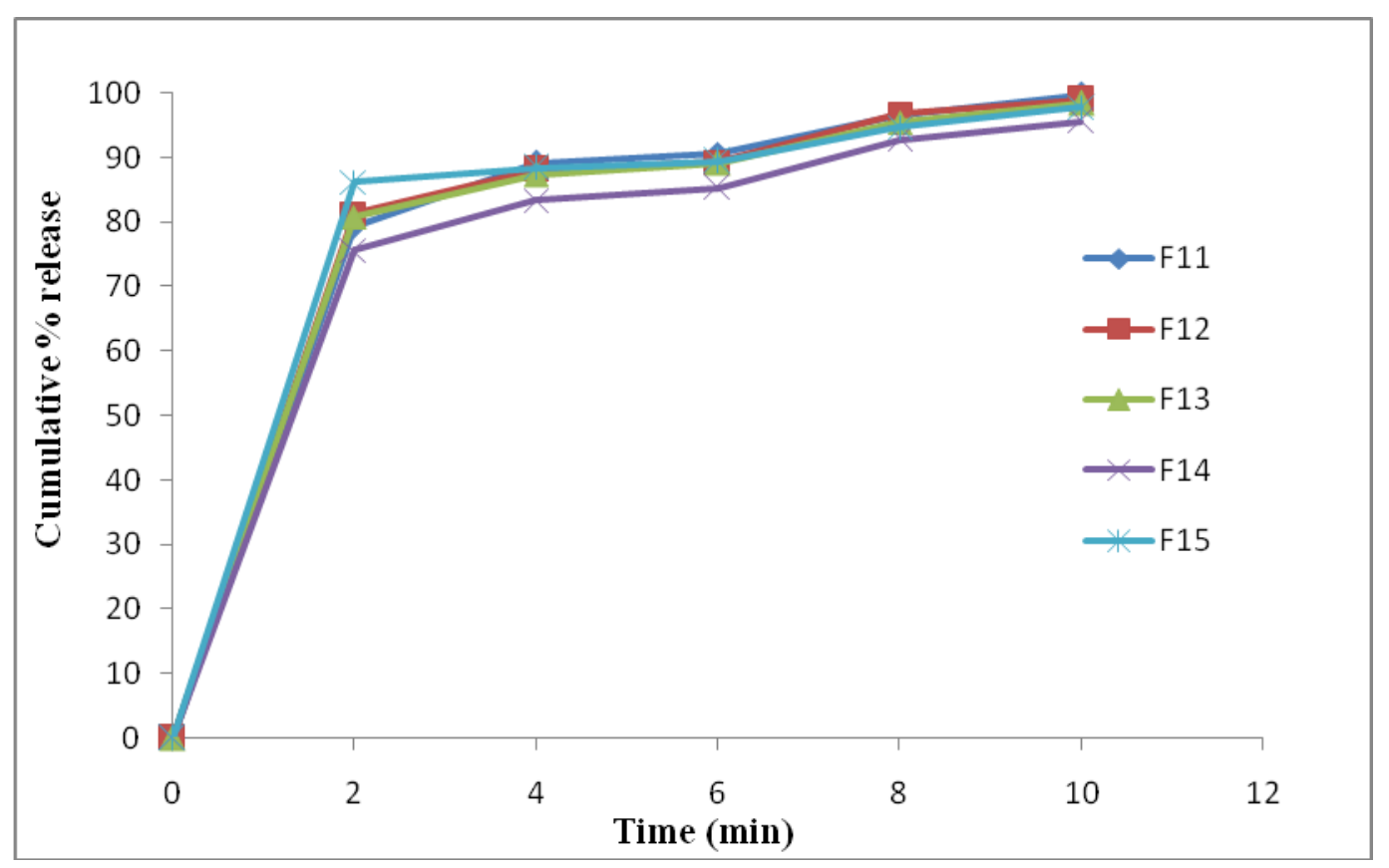

Figure 3: In-Vitro release Profile of formulation F11, F12, F13, F14 and F15

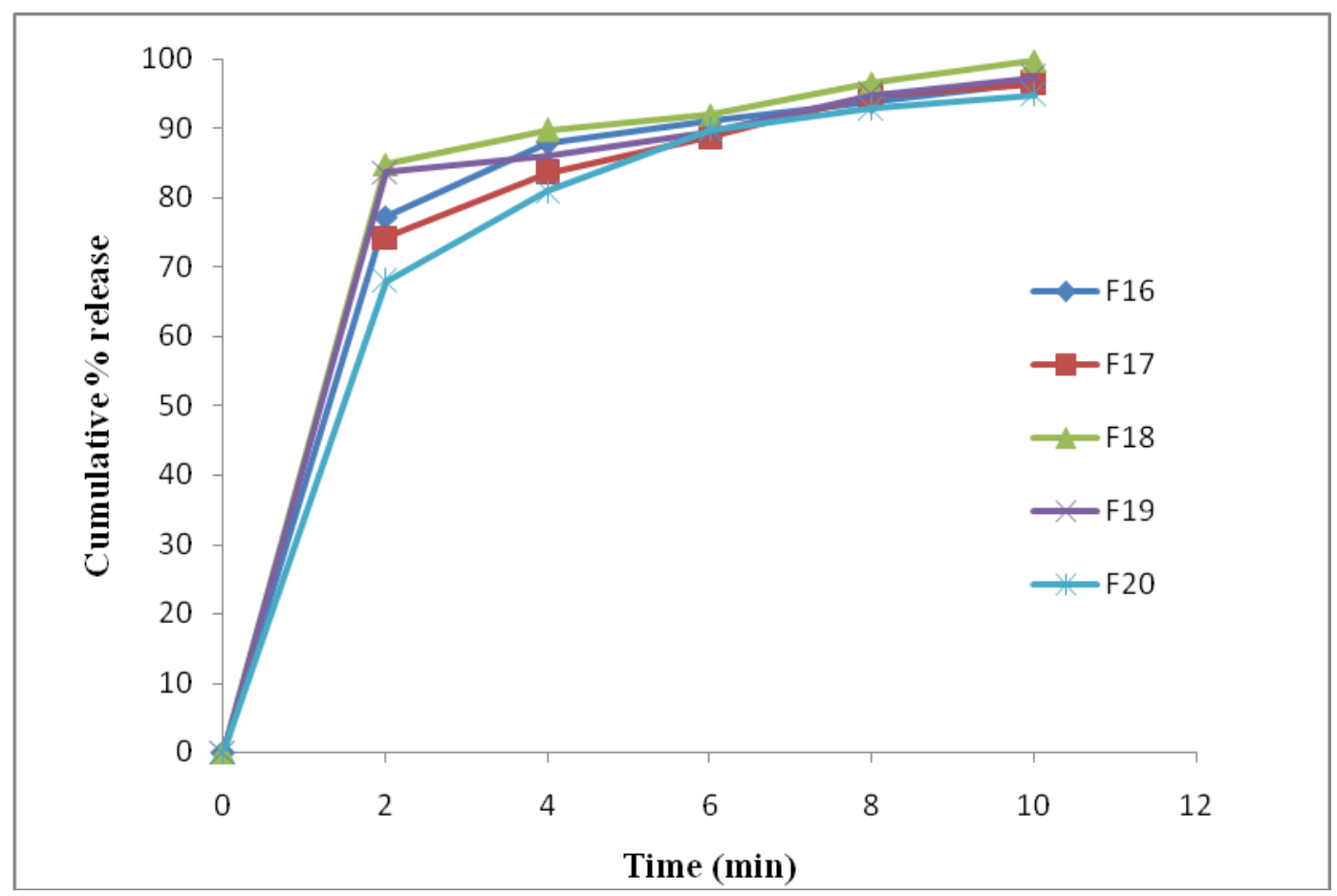

Figure 4: In-Vitro release Profile of formulation F16, F17, F18, F19 and F20 


\section{Optimization of the Formulation Fitting of Data to the Model}

According to the design, the experimental runs, their factor combinations and the levels of experimental units used in the study as well as the other formulation additives used in direct compression of tablets are summarized in Table 2. In order to determine the levels of factors which yielded optimal hardness, minimum disintegration time and maximal \% drug release in 10 minutes, mathematical relationships were generated between the dependent factors and independent variables. Using the aforementioned software, the model was fitted to the data. Regression analysis of the data was carried out in SAS (Statistical Analysis System) by a linear model. ANOVA studies represented in tables (5-7) showed that there is a statistically significant relationship between the dependent variables and the components at the $99 \%$ confidence level indicated by $P$-value ( $P$-value was $<0.01$ for all the dependent variables).

The R-Squared statistic indicated that the model as fitted explains $55.304 \%$ of the variability in hardness, $55.919 \%$ of the variability in disintegration time and $63.191 \%$ of the variability in cumulative $\%$ release. The adjusted R-squared statistic, which is more suitable for comparing models with different numbers of independent variables, was $50.0461 \%, 50.733 \%$ and $58.859 \%$ in case of hardness, disintegration time and cumulative \% release, respectively.

Table 5: ANOVA for hardness:

\begin{tabular}{|c|c|c|c|c|c|}
\hline Source & Sum of Squares & Df & Mean Square & F-Ratio & P-Value \\
\hline Linear Model & 0.332059 & 2 & 0.166029 & 10.52 & 0.0011 \\
\hline Total error & 0.268361 & 17 & 0.0157859 & & \\
\hline Total (corr.) & 0.60042 & 19 & & & \\
\hline
\end{tabular}

Table 6: ANOVA for disintegration time:

\begin{tabular}{|c|c|c|c|c|c|}
\hline Source & Sum of Squares & Df & Mean Square & F-Ratio & P-Value \\
\hline Linear Model & 85.9602 & 2 & 42.9801 & 10.78 & 0.0009 \\
\hline Total error & 67.7604 & 17 & 3.98591 & & \\
\hline Total (corr.) & 153.721 & 19 & & & \\
\hline
\end{tabular}

Table 7: ANOVA for in vitro dissolution:

\begin{tabular}{|c|c|c|c|c|c|}
\hline Source & Sum of Squares & Df & Mean Square & F-Ratio & P-Value \\
\hline Linear Model & 30.7707 & 2 & 15.3853 & 14.59 & 0.0002 \\
\hline Total error & 17.9248 & 17 & 1.0544 & & \\
\hline Total (corr.) & 48.6955 & 19 & & & \\
\hline
\end{tabular}

In order to understand the mathematical relationship between independent factors and dependent variables, regression equations were generated for each variable $(Y 1, Y 2$ and $Y 3)$ and listed in table 8. 
Table 8: Regression Equations of the fitted models

\begin{tabular}{|c|c|}
\hline Response & Equation \\
\hline Hardness $(Y 1)$ & $=3.436 X_{1}+3.747 X_{2}+2.981 X_{3}$ \\
\hline Disintegration time $\left(Y_{2}\right)$ & $=16.34 X_{1}+22.575 X_{2}+10.666 X_{3}$ \\
\hline In vitro dissolution $\left(Y_{3}\right)$ & $=96.325 X_{1}+94.321 X_{2}+101.815 X_{3}$ \\
\hline
\end{tabular}

\section{Three-dimensional (3D) Response Surface and Contour Plots:}

Based on the model polynomial functions, Three-dimensional (3D) plots for the measured variables were formed to assess the change of the response surface as well as to provide better understanding of the relationship between the dependent factors and independent variables. Response surface and contour plots of estimated response surface for the variables $Y 1$, $Y 2$ and $Y 3$ were represented in Figures (5-10). These Figures, showed the effect of components; Croscarmellose sodium \% (X1), Explotab \% (X2), and Polyplasdone XL10 \% (X3), on the properties of the prepared RB fast dissolving tablets $Y 1$ (hardness), $Y_{2}$ (disintegration time) and $Y_{3}$ (cumulative $\%$ release after 10 minutes).

The three components of the mixture were located at the corners of the triangle and the center corresponds to the mixture in equal parts. The white regions displayed in the figures represent areas not applied in the regressions, because of the constraints of the components. Consequently, variations on the mixture composition influence hardness $\left(Y_{1}\right)$, disintegration time $\left(Y_{2}\right)$, and cumulative \% release after 10 minutes $\left(Y_{3}\right)$. All regression equations of the fitted linear model for all investigated responses showed positive values for all components of the mixture demonstrating their positive effect on the responses.

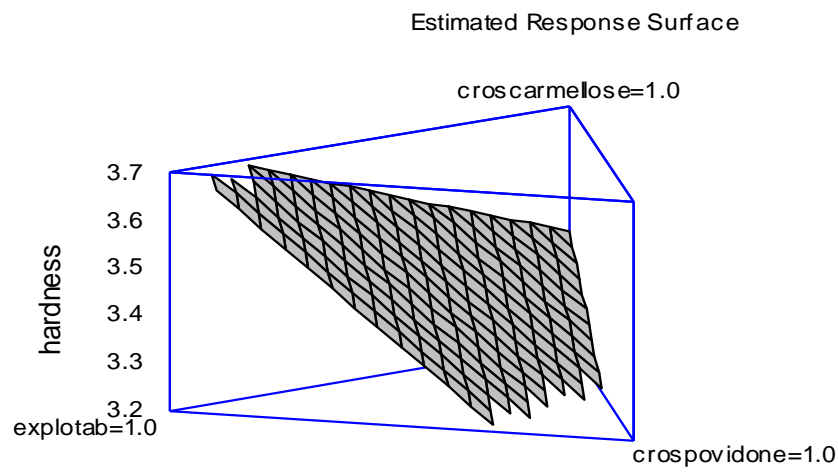

Figure 5: Response surface plot (3D) showing the effect of $X 1, X 2$, and $X 3$ on $Y 1$ response. 


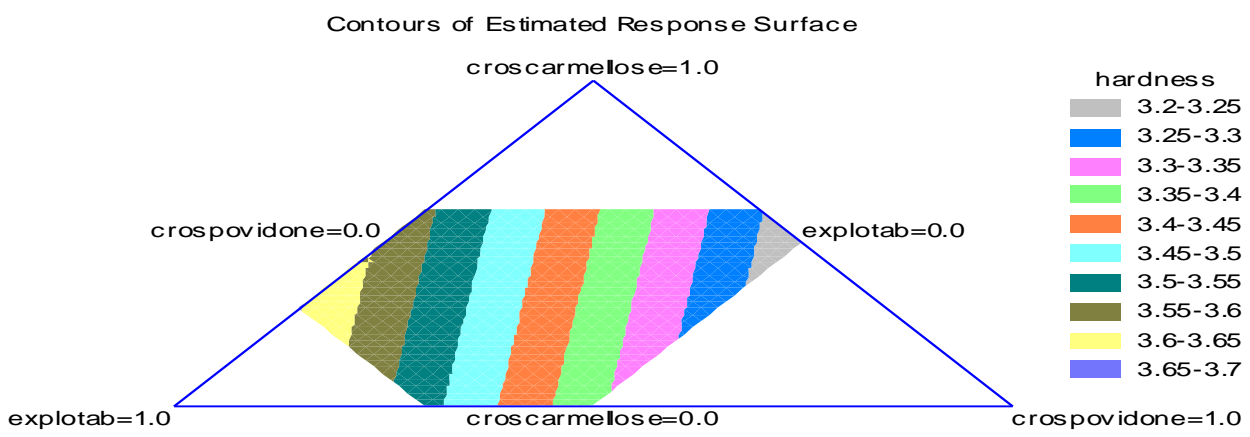

Figure 6: Contour plot of estimated response surface showing the effect of $X 1, X 2$, and $X 3$ on $Y 1$ response.

The regression equation and the triangular dimensional contours figure (6) demonstrated that higher proportions of Explotab $\left(X_{2}\right)$ and lower proportions of both $X_{1}$ and $X_{3}$ increased the hardness of the tablet. The yellow areas in Figure 6, close to the corner of Explotab in the triangle represent the highest hardness of the formulations. On the other hand, the disintegration time $\left(Y_{2}\right)$ was shown to be influenced by the mixture composition. From the contour plot (Figure 8) the shorter disintegration time was obtained at the midpoint between croscarmellose and polyplasdone XL10 with lower level of explotab which appeared in the gray area. The same finding was observed for cumulative \% release (Y3) and was shown to be influenced by the mixture composition as displayed in Figure 10. The maximum \% of drug release (98.8-99.4\%) was achieved at the center of the distance between croscarmellose and polyplasdone XL10 with lower level of explotab which appeared in the yellow area.

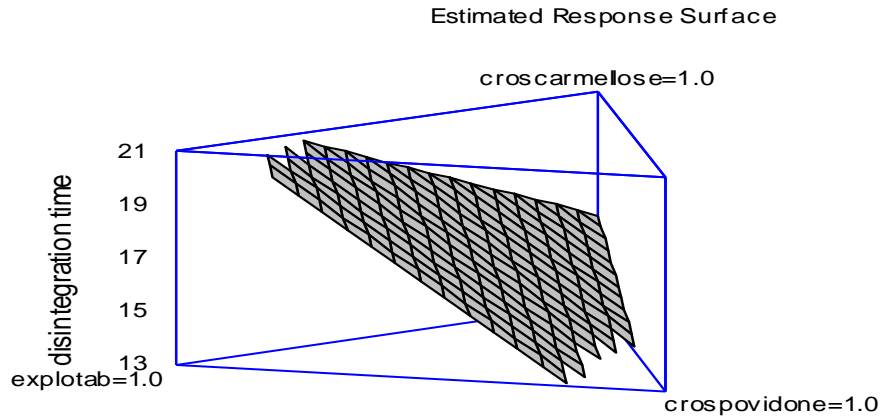

Figure 7: Response surface plot (3D) showing the effect of $X 1, X 2$, and $X 3$ on $Y 2$ response. 


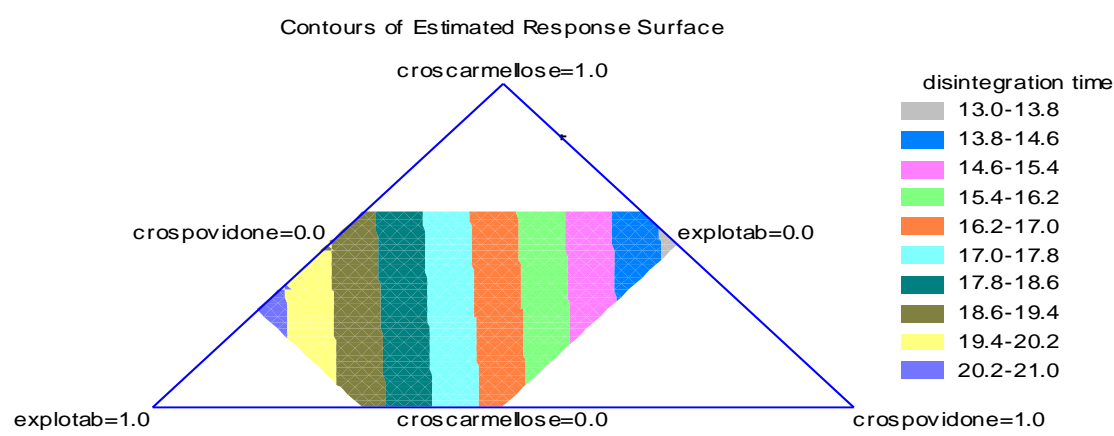

Figure 8: Contour plot of estimated response surface showing the effect of $X 1, X 2$, and $X 3$ on $Y 2$ response

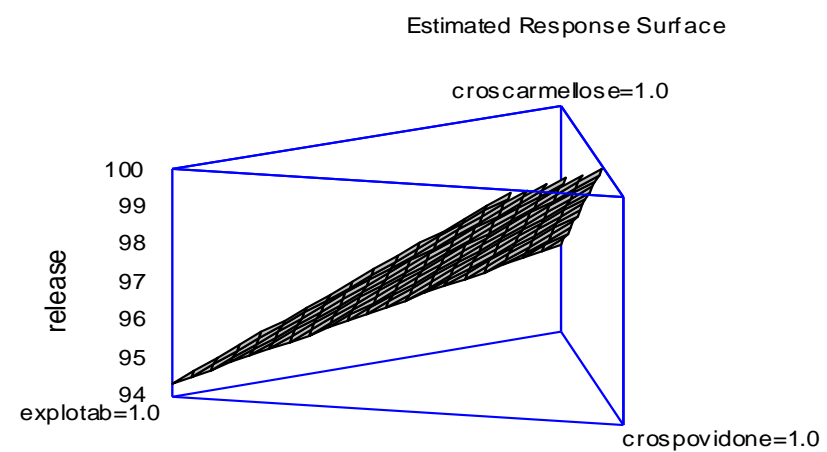

Figure 9: Response surface plot (3D) showing the effect of $X 1, X 2$, and $X 3$ on $Y 3$ response.

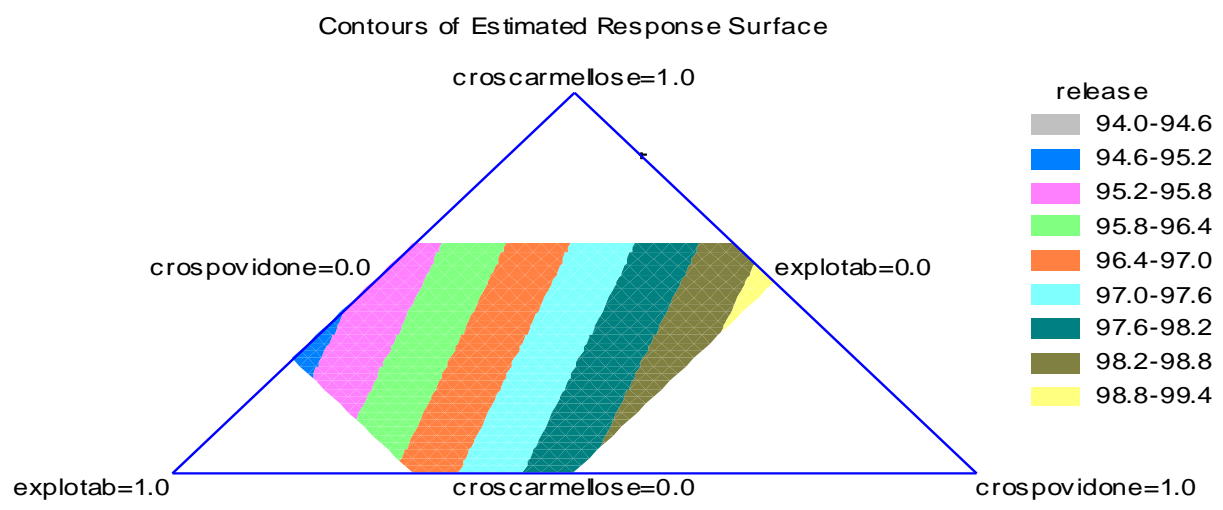

Figure 10: Contour plot of estimated response surface showing the effect of $X 1, X 2$, and $X 3$ on $Y 3$ response. 


\section{Prediction of the Optimized RB fast dissolving formulation}

After generating the model regression equations to relate the dependant factors and independent variables, the process was optimized for the dependent variables. The optimization goals for the dependent variables were set to achieve optimal hardness, minimal disintegration time and maximal in vitro \% release. The final optimal experimental factors were calculated using the canonical analysis, which allows the compromise among various dependent variables and searches for a combination of independent factor levels that jointly optimize a set of responses by satisfying the requirements for each variable in the set. The optimal calculated parameters were: Croscarmellose sodium was $0.58 \%$, Explotab was $1.92 \%$ and Polyplasdone XL10 was $2.5 \%$.

To confirm the validity of the calculated optimal factors, determination of the dependent variables (the hardness, disintegration time and in vitro drug release profile) was carried out. Table 9 illustrated the observed and predicted values for the dependent variables for the optimized RB fast dissolving tablet. Minimal differences were observed between the observed and predicted values.

Table 9: Optimum Desirability.

\begin{tabular}{|c|c|c|c|c|c|}
\hline Factor & Optimum & Response & Predicted & Observed & Residuals \\
\hline Croscarmellose & 0.58 & Hardness & 3.328 & 3.37 & 0.042 \\
\hline Explotab & 1.92 & disintegration time & 15.896 & 14.69 & -1.206 \\
\hline Polyplasdone XL10 & 2.5 & Release & 98.30 & 99.58 & 1.278 \\
\hline
\end{tabular}

\section{CONCLUSIONS}

The use of direct compression technique and the mixture experimental design succeeded to produce fast dissolving tablets of RB with optimal hardness, minimal disintegration time and maximal in vitro drug release. The quantitative effects of the selected factors tested on the different variables were explored. Based on the obtained results, fast dissolving tablets of RB could be a potential dosage form for quick relieve of migraine patients.

\section{REFERENCES}

Battu SK, Repay MA, Maunder S, Rio MY. (2007): Formulation and evaluation of rapidly disintegrating Fenoverine tablets: Effect of Superdisintegrants. Drug Dev Ind Pharm., 33, 1225-1232.

Carr RL. (1965): Classifying flow properties of solids. Chem. Eng., 1, 69-72.

Chopda Minal S. (2014): Formulation and In-Vitro Evaluation of Oro-Dispersible Tablets of Olanzapine by Direct Compression; Am. J. Pharm Tech Res. 4(5), 114-127.

Cornell JA. (1990): How to Run Mixture Experiments for Product Quality (The ASQC Basic References in Quality Control), ASQC, Milwaukee, vol. 5, p. 96.

Eriksson L, Johansson E, Wikstrom C. (1998): Mixture design: design generation, PLS analysis, and model usage. Chemomet. Intell. Lab. Syst., 43, 1-24. 
European Directorate for the Quality of Medicines, (2006): https://www.edqm.eu/europeanpharmacopoeia- 5.2, 3151 .

Evren Alğin Yapar (2014): Orally Disintegrating Tablets: An Overview, Journal of Applied Pharmaceutical Science Vol. 4 (02), pp. 118-125.

Hindustan A, Chitta K, Kishor R, Anil B, Chandra A, Sushma K, Sairam T, Sivaji S. A. (2010): A novel technique in formulation and evaluation of mouth dissolving nimesulide tablets. J Advanced Pharma Res; 1(2): 101-107.

Indurwade NH, Rajyaguru TH, Nakhat PD. (2002): Novel approach-fast dissolving tablets. Indian Drugs, 39(8), 405-9.

Kakade SM, Mannur VS, Ramani KB, Dhada AA, Naval CV, Bhagwat A. (2010): Formulation and evaluation of mouth dissolving tablets of losartan potassium by direct compression techniques. Int. J. Res. Pharm. Sci., 1, 3, 290-295.

Keny R. V., Chrisma Desouza, and Lourenco C. F. (2010): Formulation and Evaluation of Rizatriptan Benzoate Mouth Disintegrating Tablets, Indian J Pharm Sci. 72(1): 79-85.

Kumara Swamy S, Narender D., Agaiah Goud . (2012): Formulation and evaluation of orodispersible tablet of theophylline using different super disintegrants. J Advanced Pharma Sci.; 2(2): 260-264.

Martindale, the Complete Drug Reference. Sweetman SC, 33 ${ }^{\text {rd }}$ Ed., (2002): The Pharmaceutical Press, London, Antimigraine Drugs; pp. 445-46, Electronic version.

Martinello T, Kaneko MT, Velasco MVR, Taqueda MES, Consiglieri OV., (2006): Optimization of poorly compactable drug tablets manufactured by direct compression using the mixture experimental design. Int. J. Pharm., 322, 87-95.

Mohire N, Yadav A, Gaikwad V., (2009): Novel approaches in development of metronidazole orodispersible tablets; Research J Pharm. and Tech; 2(2): 283-286.

Mukeshi PR, Mohanta GP, Lokesh U. (2009): Review on: Fast dissolving tablet. Journal of pharmacy research., 2(1), 5-12.

Nyol S, Gupta M., (2013): Immediate drug release dosage form: a review. J Drug Delivery \& Therapeutics; 3(2):155-161.

Parakh SR, Gothoskar AV. (2003): A Review of Mouth Dissolving Tablet Technologies, Pharm. Technol., 27(11), 92-100.

Patidar A , Mishra P, Main p, Harsoliya MS and Agrawal S. (2011): A review on- recent advancement in the development of rapid disintegrating tablet. Int. Journal of Life science and Pharma Research; 1: 7-16. 
Que L, Wu W, Cheng X, Hu T., (2006): Evaluation of disintegrating time of rapidly disintegrating tablets by a paddle method. Pharm Dev Technol. 11:295-301.

Sanders-Bush E, Mayer SE. (2006): 5-hydroxytryptamine (Serotonin): Receptor agonists \& antagonists. In: Brunton LL, Lazo JS, Parker KL, editors. Goodman \& Gilman's The Pharmacological Basis of Therapeutics. 11th ed. New York: McGraw Hill; pp. 305-9.

Yutaka M, Yuki T, Masanobu Y, Ryoji T, Junko A, Kozo T. (2002): Evaluation of the disintegration time of rapidly disintegrating tablets via a novel method utilizing a CCD camera. Chem. Pharm. Bull., 50(9), 1181-1186.

ريزاتريبتان بنزوات أقراص سريعة الذوبان لتخفيف الصداع النصفى: تصميح, تظوير وتوصيف

$$
\text { قسم الصيدلانيات و الصيدلة الصناعية - كلية الصيدلة - جامعة الأزهر - القاهرة - ج.م.ع ابر اهيم عبداله ابر اهيم }
$$

ريزاترييتان بنزوات هو أحد عقاقير الجيل الجديد من مضادات الصداع النصفى ويصل أعلى تركيز له فى الدم بعد

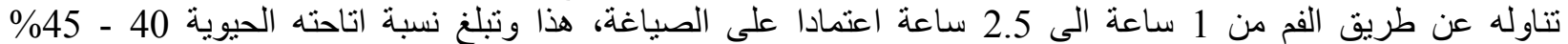

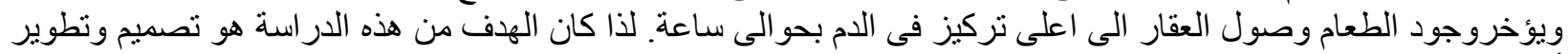

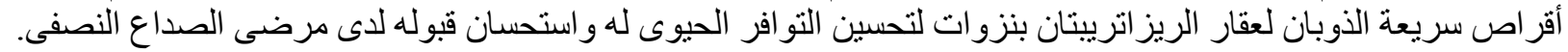

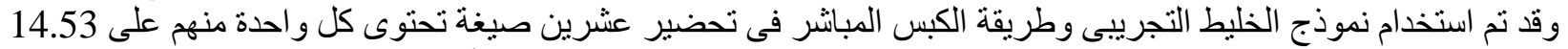

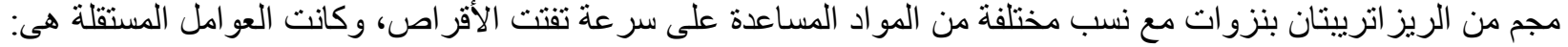

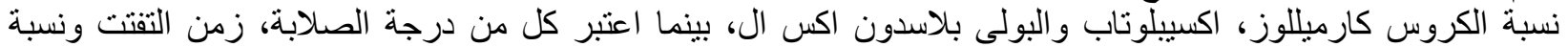

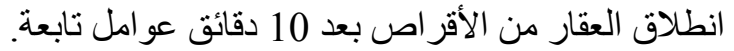

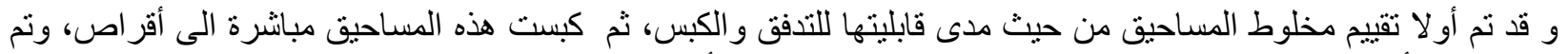

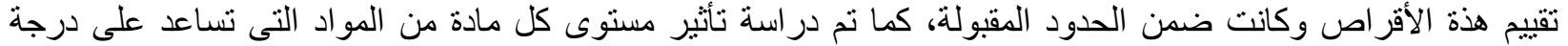

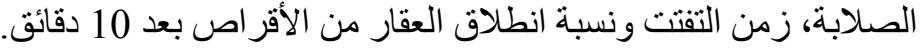

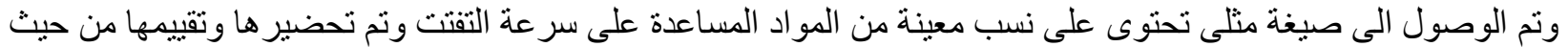

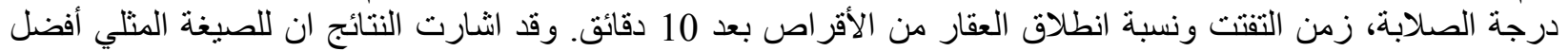

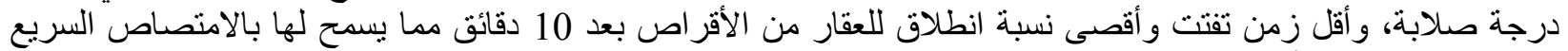

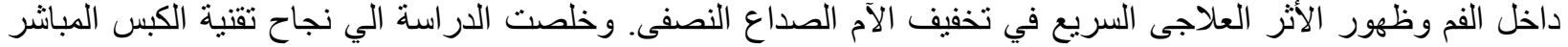
ونموذج الخليط التجريبى للاقر اص في استمثال صيغة تحقق الغرض المرجو منها في زيادة الاتاحة الحيوية للعقار. 